\title{
Cbp/p300-Interacting Transactivator 2
}

National Cancer Institute

\section{Source}

National Cancer Institute. Cbp/p300-Interacting Transactivator 2. NCI Thesaurus. Code C126435.

Cbp/p300-interacting transactivator 2 (270 aa, $\sim 28 \mathrm{kDa}$ ) is encoded by the human CITED2 gene. This protein plays a role in the positive regulation of gene expression. 